\title{
Review of the Swedish Enicospilus (Hymenoptera; Ichneumonidae; Ophioninae) with description of three new species and an illustrated key to species
}

\author{
Niklas JOHANSSON \\ Fredriksberg/Baskarp, 56692 Habo, Sweden. \\ Email: chrysis32@yahoo.se \\ urn:lsid:zoobank.org:author:4BB5F059-B4EE-41F9-8313-B529164B1FA6
}

\begin{abstract}
The Swedish species of Enicospilus are reviewed. Three species are described from Swedish material; Enicospilus cederbergi sp. nov., Enicospilus intermedius sp. nov. and Enicospilus ryrholmi sp. nov. Four species: Enicospilus cerebrator Aubert, 1966, Enicospilus combustus (Gravenhorst, 1829), Enicospilus merdarius (Gravenhorst, 1829) and Enicospilus myricae Broad \& Shaw, 2016, are reported from Sweden for the first time. An illustrated key to the Swedish species of Enicospilus is provided. Validity of the new species is supported by DNA barcoding.
\end{abstract}

Keywords. Enicospilus, barcoding, new species, Sweden, Ophioninae.

Johansson N. 2018. Review of the Swedish Enicospilus (Hymenoptera; Ichneumonidae; Ophioninae) with description of three new species and an illustrated key to species. European Journal of Taxonomy 483: 1-21. https://doi.org/10.5852/ejt.2018.483

\section{Introduction}

Enicospilus Stephens, 1835 is a genus within the subfamily Ophioninae which consists of large, testaceus nocturnal Ichneumonidae with large ocelli and long antennae. Enicospilus species in Northern Europe are distinguished from other Ophioninae by the narrow twisted mandibles and a large glabrous area in the fore wing discosubmarginal cell, often displaying one or two sclerites. The known hosts of European Enicospilus are Lasiocampidae and Noctuidae, feeding on shrubs and herbs (Broad \& Shaw 2016).

Previous revisonal work has been carried out by several authors, at least partly treating the European fauna (Kokujev 1907; Shestakov 1926; Viktorov 1957; Bordera et al. 1987; Broad \& Shaw 2016) and besides the main revisions several new taxa have been described in various papers (Aubert 1966, 1979; Izquierdo 1983).

In Sweden, a majority of the species of Enicospilus belong to the monophyletic Enicospilus ramidulus (Linnaeus, 1758) species group. This species group is defined by the combination of having both the proximal and central sclerites present and a longitudinal setose groove on the mandible. The presence of two pigmented sclerites in the fore wing is a feature also shared by the primarily tropical E. antefurcalis species group (Gauld \& Mitchell 1981; Gauld 1988; Broad \& Shaw 2016; Shimizu 2017). Due to 
some unfortunate misidentifications and synonymizations, the species within the E. ramidulus species group have been partly misinterpreted historically. Broad \& Shaw (2016) revised the British fauna and resolved some of the taxonomic confusion, thereby preparing a foundation for further revisions. This paper, which treats the Swedish species of Enicospilus, including the description of three new species of the E. ramidulus group from Sweden, adds another piece to the Western Palaearctic puzzle.
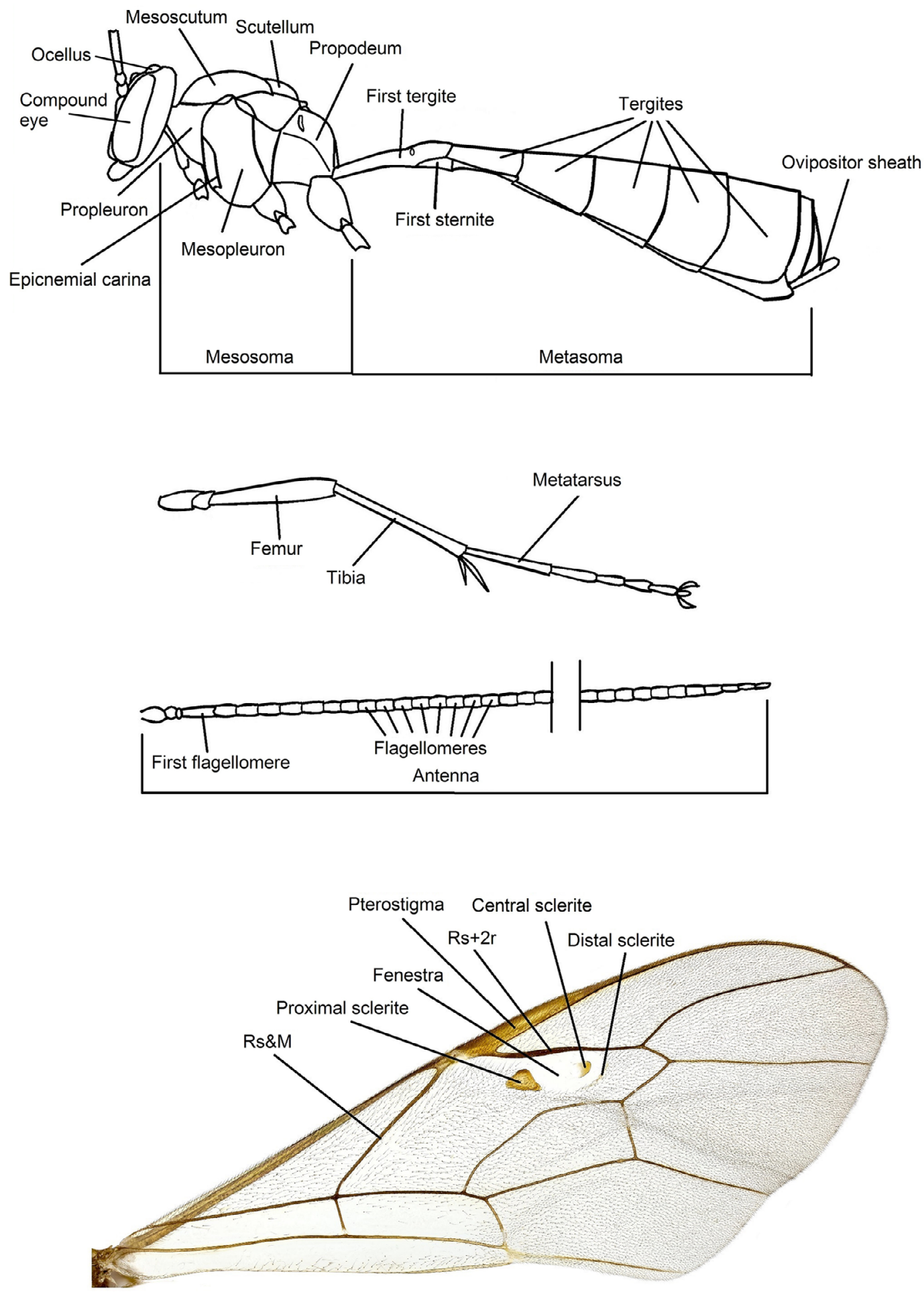

Fig. 1. Morphological terminology referred to in the text. 


\section{Material and methods}

Material of Swedish Enicospilus was mainly obtained from private butterfly collectors, the vast and longlasting survey with MV-light traps conducted by Nils Ryrholm and Clas Källander, and the Swedish Malaise trap project (SMTP). The author also studied specimens deposited in Biologiska Museet in Lund (MZLU) and Naturhistoriska Riksmuseet in Stockholm (NHRS). The material was sorted and clustered into morphospecies which were then compared to available and relevant type material. DNA barcoding of representatives for each morphospecies focused on the sequencing of a standardized 658 base pairs segment of the mitochondrial cytochrome c oxidase I gene (COI). This method has been proposed for species discovery, identification and delimitation (Hebert et al. 2003). The combination of classical morphometrics and barcoding has been shown to be a very accurate method in species delimitation (Schwarzfeld \& Sperling 2014) as COI analysis alone is not sufficient to exclude distorting factors such as hybridization and high intraspecific variation (Funk \& Omland 2003; Klopfstein et al. 2016). The barcodes are stored in BOLD; BIN-codes, as well as specimen codes (STI:NJBC "X") are given in the text. Morphological terminology (Fig. 1) follows Gauld $(1988,1991)$ and Broad \& Shaw (2016). Photos of the habitus lateral and head in anterior and lateral view were taken by the author using an Olympus OMD M10 and an Olympus M. Zuiko 60mm/f.2.8 macro lens. All other photos were taken by Krister Hall using a Canon eos 5dr with a Mitutoyo 5x Plan Apo Infinity corrected/Mitutoyo 10x Plan Apo Infinity corrected lens (microscopic pictures) and a Canon mp-e $65 \mathrm{~mm} \mathrm{f} / 2.81-5 \mathrm{x}$ for pictures of the wing details and stacked using Zerene Stacker, except Fig. 2A by Michael Andersson.

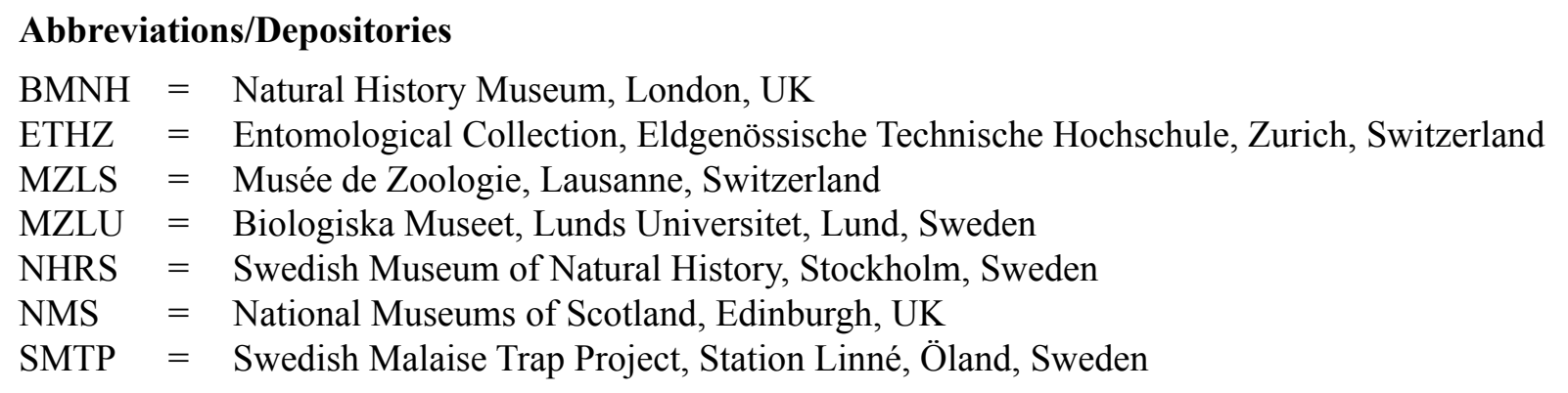

Results

Class Hexapoda Blainville, 1816

Order Hymenoptera Linnaeus, 1758

Superfamily Ichneumonoidea Latreille, 1802

Family Ichneumonidae Latreille, 1802

Subfamily Ophioninae Shuckard, 1840

Genus Enicospilus Stephens, 1835

\section{Description of the new species}

Enicospilus cederbergi sp. nov. urn:lsid:zoobank.org:act:9368EFAF-9601-4672-843F-A9EE71B82DB0

Figs $2 \mathrm{~A}-\mathrm{B}, 3 \mathrm{C}-\mathrm{D}, 4 \mathrm{~B}, 5 \mathrm{~B}, 7 \mathrm{~B}, 10$

\section{Diagnosis}

Enicospilus cederbergi sp. nov. (Fig. 2A-B) can be distinguished from other members of the E. ramidulus species group based on the relatively stout habitus and legs, the short but numerous flagellomeres, the slightly sinuate Rs\&M-vein, the infuscate and thickened veins in the fore wings and the infuscate margins of the pterostigma. Specimens with an infuscate tip of the metasoma are most likely to be 
confused with E. ramidulus Linnaeus, 1758, while the thicker antennal segments are reminiscent of E. cerebrator Aubert, 1966. Also similar and probably closely related to E. intermedius sp. nov. but distinguishable from that species on the stouter and less numerous flagellomeres.

\section{Etymology}

The name cederbergi refers to Björn Cederberg who is devoted to popularizing Hymenoptera in Sweden.
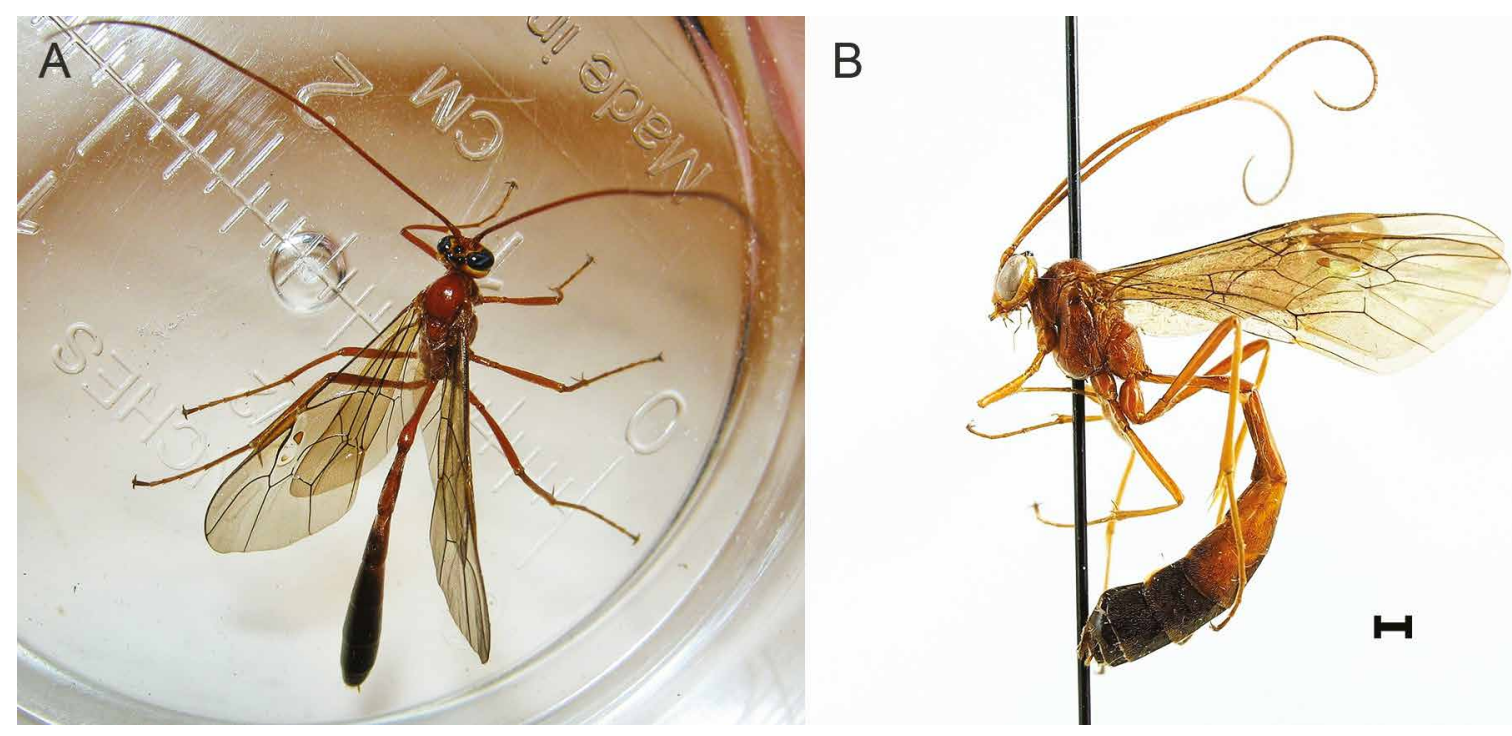

Fig. 2. Enicospilus cederbergi sp. nov., holotype, $q$ (NHRS-HEVA00008145). A. Habitus, dorsolateral view. B. Habitus, lateral view. Scale bar $=1 \mathrm{~mm}$.

A

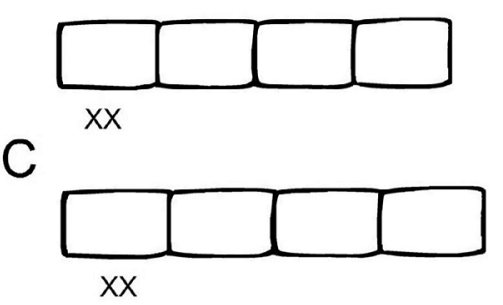

$\mathrm{E}$

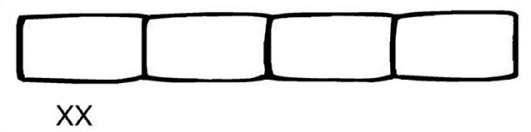

G

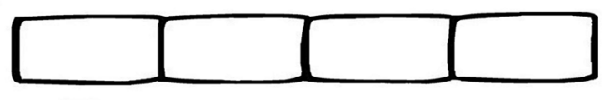

B

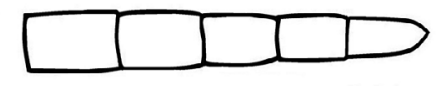

$\mathrm{D}$

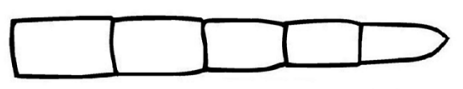

$\mathrm{F}$

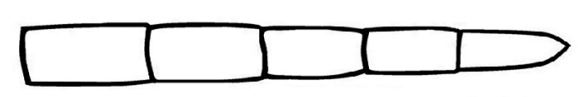

$\mathrm{H}$

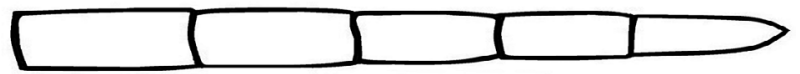

Fig. 3. Central and apical flagellomeres. A-B. Enicospilus cerebrator Aubert, 1966. C-D. E. cederbergi sp. nov., paratype, + (NHRS-HEVA000008148). E-F. E. adustus (Haller, 1885). G-H. E. ryrholmi sp. nov., paratype, + (NHRS-HEVA000008173). 
Material examined $(\mathrm{n}=12$ 우, 5 ふえ$)$

\section{Holotype}

SWEDEN: 1 , , Öland, Mörbylånga, Strandskogen, $56.698^{\circ} \mathrm{N}, 16.496^{\circ} \mathrm{E}, \mathrm{MV}-$ light in garden close to an oak forest and sandy meadow, 24 Jun. 2016, M. Andersson leg. (NHRS-HEVA000008145 STI:NJBC155).

\section{Paratypes}

SWEDEN: 7 우, 3 $\widehat{\partial}$, Skåne, Simrishamn, Järahusen, $55.411^{\circ} \mathrm{N}, 14.195^{\circ}$ E, MV-light trap, 8-28 Jul. 2016, N. Ryrholm and C. Källander leg. (NHRS-HEVA000008146-NHRS-HEVA000008155; $1 \delta^{\Uparrow}$ NHRS-HEVA000008155 STI:NJBC157, 1 +, NHRS-HEVA000008150 STI:NJBC158); 1 \&, Skåne, Ystad, Kåseberga, $55.385^{\circ} \mathrm{N}, 14.069^{\circ} \mathrm{E}, \mathrm{MV}$-light trap in semi-open coastal meadow, 11 May-27 Jul. 2016, N. Ryrholm and C. Källander leg. (NHRS-HEVA000008156); $2 \hat{\jmath} \widehat{\jmath}$, Sörmland, Tyresta, Nationalparken urskogsslingan, $59.105^{\circ} \mathrm{N}, 18.148^{\circ} \mathrm{E}$, Malaise trap in old semi-open coniferous forest, 2 Jul.-21 Aug. 2003 SMTP leg. (NHRS-HEVA000008157, NHRS-HEVA000008158 STI:NJBC156); 1 đิ, Öland, Mörbylånga, Strandskogen, $56.698^{\circ} \mathrm{N}, 16.496^{\circ} \mathrm{E}, \mathrm{MV}$-light in garden close to an oak forest and sandy meadow, 16 Jun. 2016, B. Andersson leg. (NHRS-HEVA000008159); 1 +, Småland, Gnosjö, Kittlakull Store mosse, $57.172^{\circ} \mathrm{N}, 15.551^{\circ} \mathrm{E}$, Malaise trap in pine bog, 12 Jul.-21 Aug. 2003, SMPT leg. (NHRS-HEVA000008160); 1 ㅇ, Uppland, Häverö, Västersnäs, $60.114^{\circ} \mathrm{N}, 18.616^{\circ} \mathrm{E}$, MV-light trap, 4-7 Sep. 2017, N. Ryrholm and C. Källander leg. (NHRS-HEVA000008161 STI:NJBC285); 1 q,

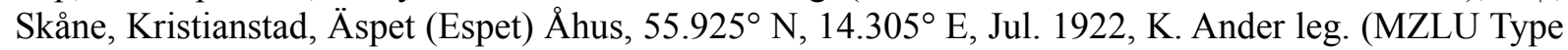
no. 06122:2); 1 ㅇ, Västergötland, Habo, Brandstorp, $58.097^{\circ} \mathrm{N}, 14.206^{\circ}$ E, 2 Jul. 1948, T.-E. Leiler leg.

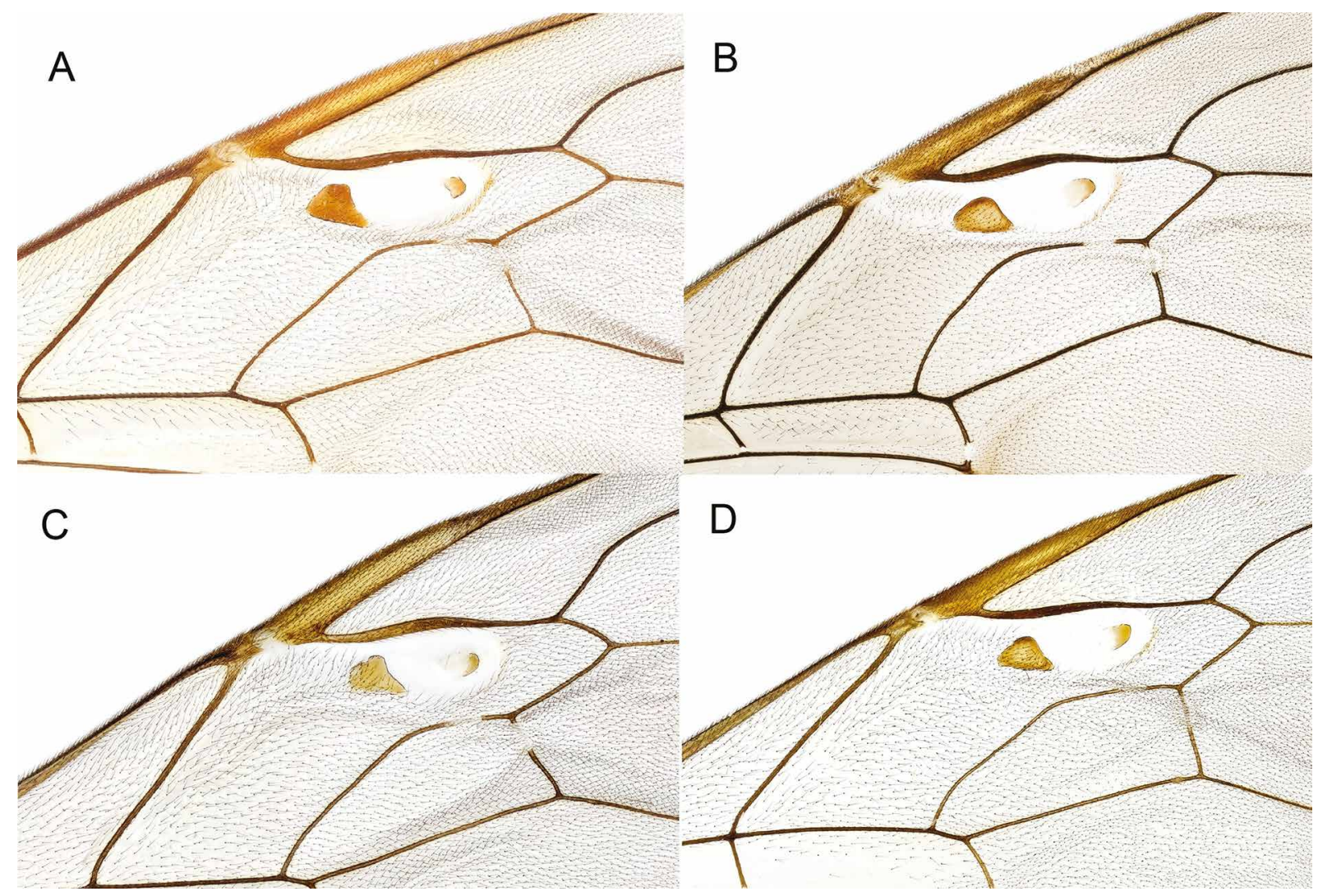

Fig. 4. Central part of fore wing. A. Enicospilus combustus (Gravenhorst, 1829), ․ B. E. cederbergi sp. nov., paratype, $q$ (NHRS-HEVA000008146). C. E. ryrholmi sp. nov., paratype, $q$ (NHRSHEVA000008173). D. E. adustus (Haller, 1885), ․ . 
(NHRS-HEVA000003806); 1 ㅇ, Halland, Halmstad, Örnäsudden, 56.652 ${ }^{\circ} \mathrm{N}, 12.806^{\circ}$ E, 20 Jul. 1954, B.-H. Hanson leg. (NHRS-HEVA000003807).

\section{Description}

\section{Female}

Body length 18-20 mm. Fore wing length $13-15 \mathrm{~mm}$. Number of flagellomeres 58-61 (mean 59.5). Mandible strongly twisted with upper tooth two times as long as lower tooth. First flagellomere relatively stout, about 3.5-4.0 times as long as apically wide. Mid- and subapical flagellomeres about 1.5 times as long as wide (Fig. 3C-D), slightly longer than average in E. cerebrator. Head in dorsal view always with distinct gap of about 0.2 times ocellar diameter between inner orbit of compound eye and lateral

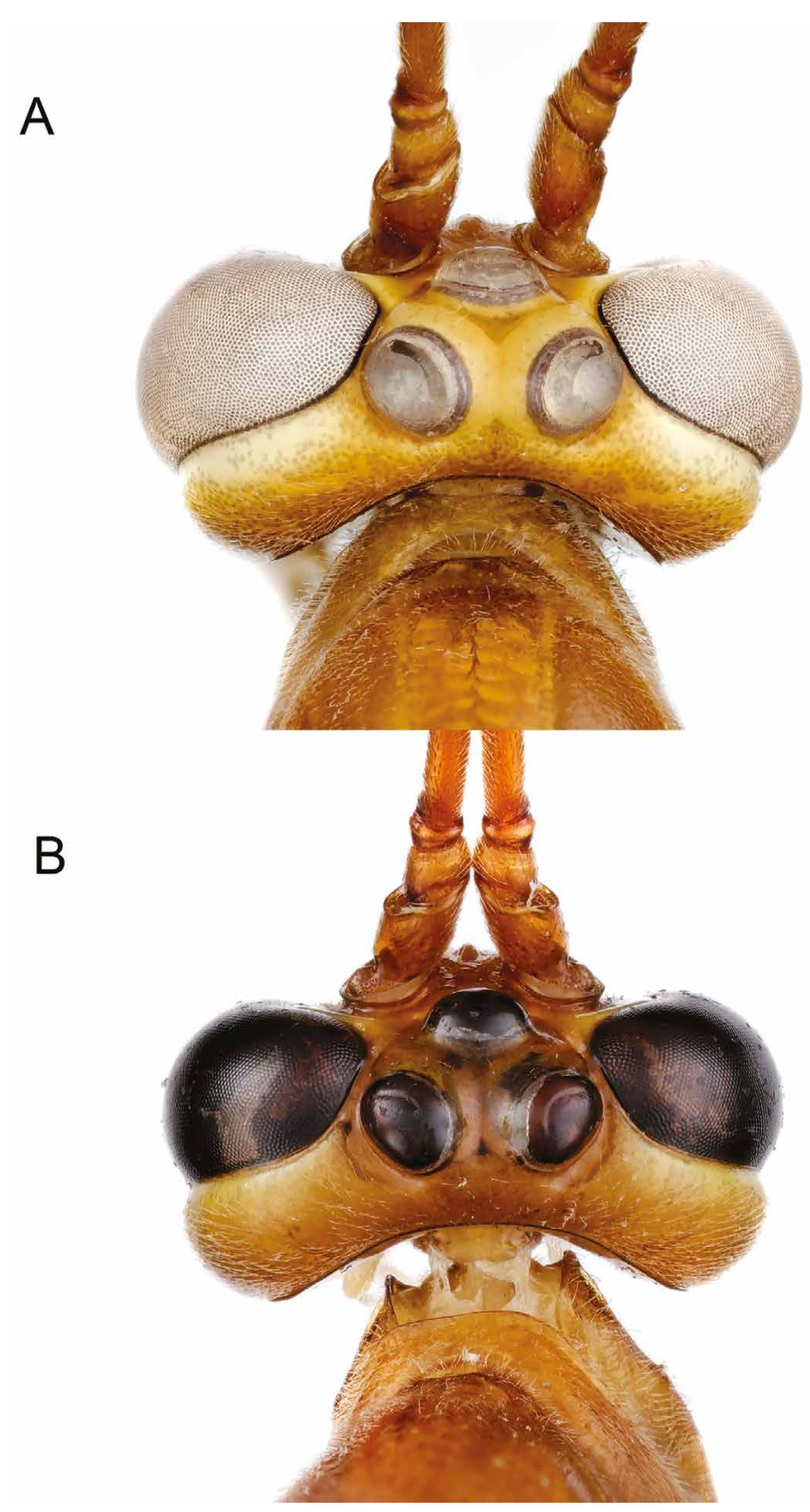

Fig. 5. Head, dorsal view. A. Enicospilus cerebrator Aubert, 1966, ․ . B. E. cederbergi sp. nov., paratype, $q$ (NHRS-HEVA000008149). 
ocellus (Fig. 5B). Temples buccate, in dorsal view curved, rounded immediately behind eye, usually distinctly wider than in E. adustus (Haller, 1885) and in lateral view about 0.7 times width of compound eye. Occipital carina conspicuously curved before indicated junction with hypostomal carina. Indicated angle between occipital carina and hypostomal carina slightly acute or right angled (as in Fig. 6A). Clypeus apically truncate, moderately convex, in lateral view almost right angled, sparsely punctate, interstices shining. Mesopleuron closely punctate on a polished background, centrally becoming more rugose, intermixed with transverse striae as in typical specimens of $E$. adustus but interstices between punctures normally wider, about equal to diameter of punctures. Epicnemial carina ventrally complete, sinuate, often indistinct or absent dorsally well before indicated joint with propleuron. Mesoscutum with notauli weakly indicated anteriorly, entirely closely punctate. Scutellum with lateral carinae, its surface with dense punctures, punctures larger than on mesoscutum. Sides of scutellum rather parallel,
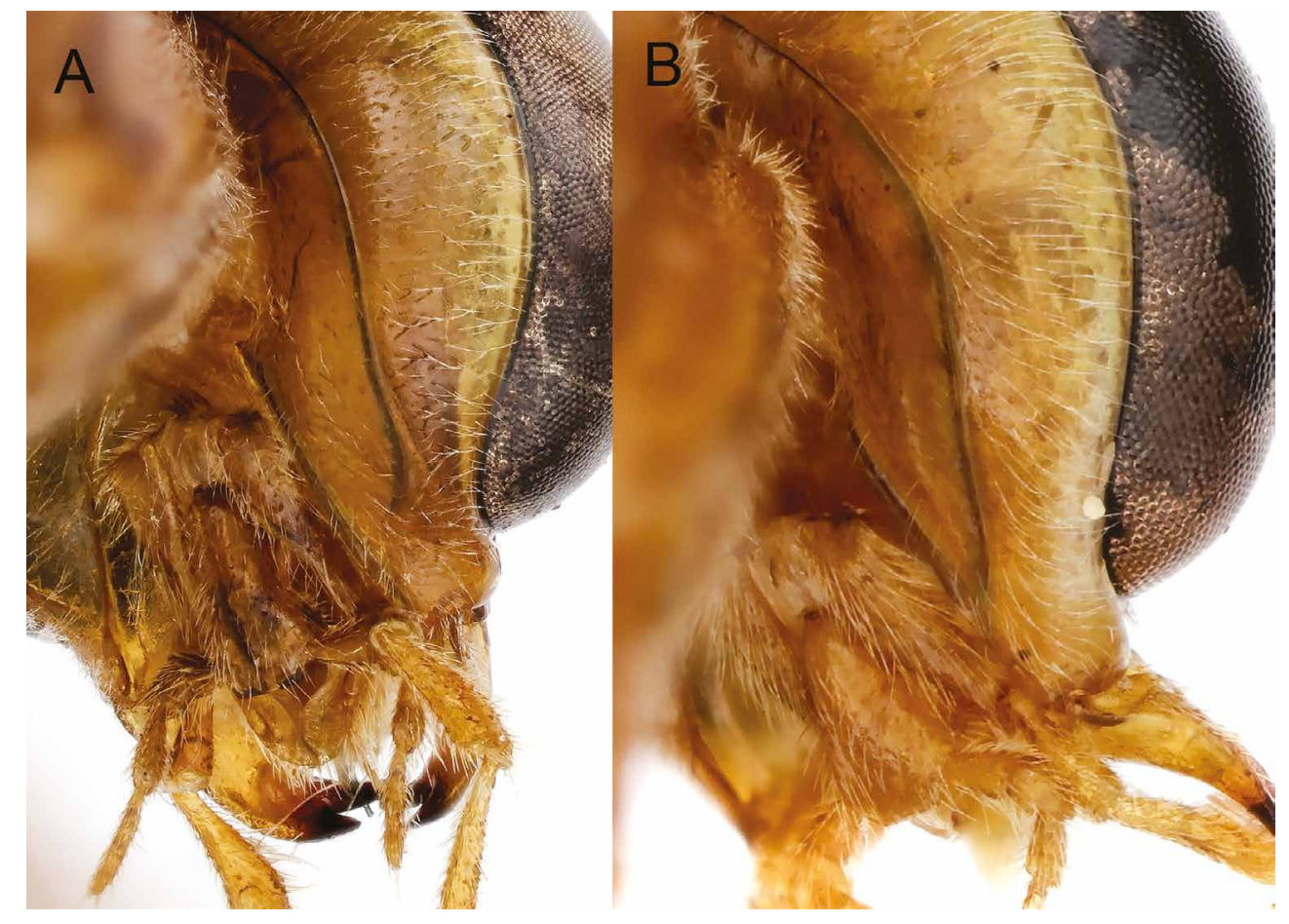

Fig. 6. Occipital carina, postero-ventral view. A. Enicospilus adustus (Haller, 1885), ㅇ. B. E. ryrholmi sp. nov., paratype, + (NHRS-HEVA000008149).

A

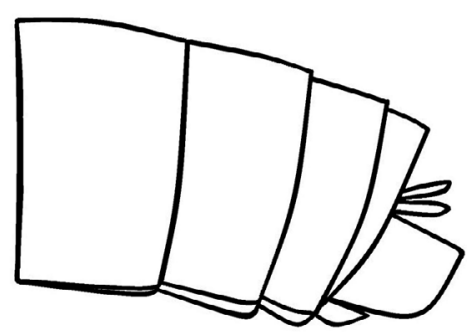

B

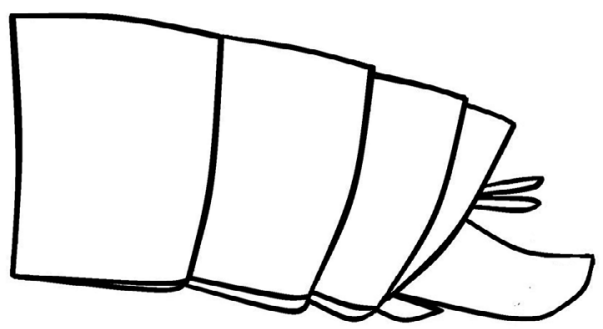

Fig. 7. Posterior metasomal segments and male parameres in lateral view. A. Enicospilus ryrholmi sp. nov., paratype, $\widehat{\partial}$ (MZLU Type no. 06123:10). B. E. cederbergi sp. nov., paratype, $\widehat{\partial}$ (NHRSHEVA000008154). 
apically and proximally wider than in E. ramidulus. Sclerites in fore wing (Fig. 4B) reminiscent of other species in the E. ramidulus group. Proximal sclerite entirely pigmented, approximately triangular with rounded anterior angle, central sclerite semi-circular, pigmented distally, fading to unpigmented proximally. Distal sclerite generally more prominent than in other Swedish species of the E. ramidulus group, represented by a relatively distinctly pigmented crescent along distal margin of fenestra. Fore wing veins thickened, black or dark brown. Pterostigma centrally pale brownish with margins more or less infuscate. Vein Rs\&M distinctly sinuate, conspicuously bent at least in lower third (Fig. 4B). Vein Rs $+2 r$ strongly thickened, distinctly sinuate. Propodeum with anterior transverse carina strong, anterior of carina rather densely punctate, posterior entirely reticulate-rugose often with faint longitudinal striae centrally. Legs usually thicker than in other members of E. ramidulus group. Hind femur about 7-8 times as long as wide. Hind metatarsus about 10 times as long as wide. Hind claws short, more strongly curved than in E. adustus but significantly less than in E. ramidulus.

\section{Male}

Size, structure and colour as in female but generally with more flagellomeres (63-64) and striation on mesopleuron feebler in studied specimens, basically absent medio-ventrally. Parameres long, in lateral view reminiscent of E. adustus (Fig. 7B).

Based on the limited material of males and the fact that the parameres often are slightly deformed due to storage and chemical treatment, no detailed description can be made of the shape of the genitalia at this stage.

\section{Colour}

Uniformly reddish brown. Inner and outer eye margins yellowish; mandibular teeth black. Metasoma usually with infuscation from 5th tergite onwards (Fig. 2), posterior tergites usually totally infuscate, black or dark brown. Ovipositor sheath of same colour as posterior metasomal segments. In some specimens infuscation of metasomal tip is partly reduced or absent. Antennae darker in apical half, terminal segment paler.

\section{DNA barcode}

The full DNA barcode sequences of five specimens of the Swedish E. cederbergi sp. nov. specimens are available at the BOLD systems database (www.boldsystems.org, BIN; BOLD:AAI5191).

\section{Distribution}

Enicospilus cederbergi sp. nov. is so far only known from Sweden. In the BOLD database there are also specimens from Germany and Israel that seem to share the genotype, but these specimens have not been studied and might refer to E. intermedius sp. nov. In Sweden it seems to be rare but widespread and known from the southern and central parts of the country (Skåne, Småland, Öland, Uppland).

\section{Phenology}

The dates on the labels of the type series indicate that the species occurs mainly during July.

\section{Ecology}

No detailed information on the biology of $E$. cederbergi sp. nov. is known. The habitat of known localities ranges from coniferous to deciduous forests in coastal areas, as well as an inland pine bog and semi-open calcareous heathland. 
Enicospilus intermedius sp. nov.

urn:lsid:zoobank.org:act:08FEDAED-6F73-4BE9-BFEA-74EBD882B0E1

Figs $8,9 \mathrm{~A}-\mathrm{C}, 10$

\section{Diagnosis}

Enicospilus intermedius sp. nov. (Fig. 8) is superficially similar to E. myricae Broad \& Shaw, 2016, but it is separated from that species by the larger size, the more numerous flagellomeres and the wider head in frontal view. Also very similar to $E$. adustus but with face wider and head more buccate behind the eyes. The face is usually entirely testaceous without yellowish areas. The only barcoded specimen shows very little genetic differentiation from E. cederbergi sp. nov. (Fig. 10) and the two species share the same BIN. Besides the differences in colour between typical specimens, the two species are distinguishable by the shape and number of the flagellomeres.

\section{Etymology}

The species is morphologically intermediate in relation to E. adustus and E. myricae.

Material examined $(\mathrm{n}=14$ 우, $3 \hat{\jmath} \widehat{\jmath})$

\section{Holotype}

SWEDEN: 1 , , Gotland, Kräklingbo, Torsburgen, $57.412^{\circ} \mathrm{N}, 18.726^{\circ} \mathrm{E}, \mathrm{MV}$-light in semi-open, herb rich, scots pine forest, 20 Jul. 2017, J. Törnvall leg. (NHRS-HEVA000008162 STI:NJBC273).

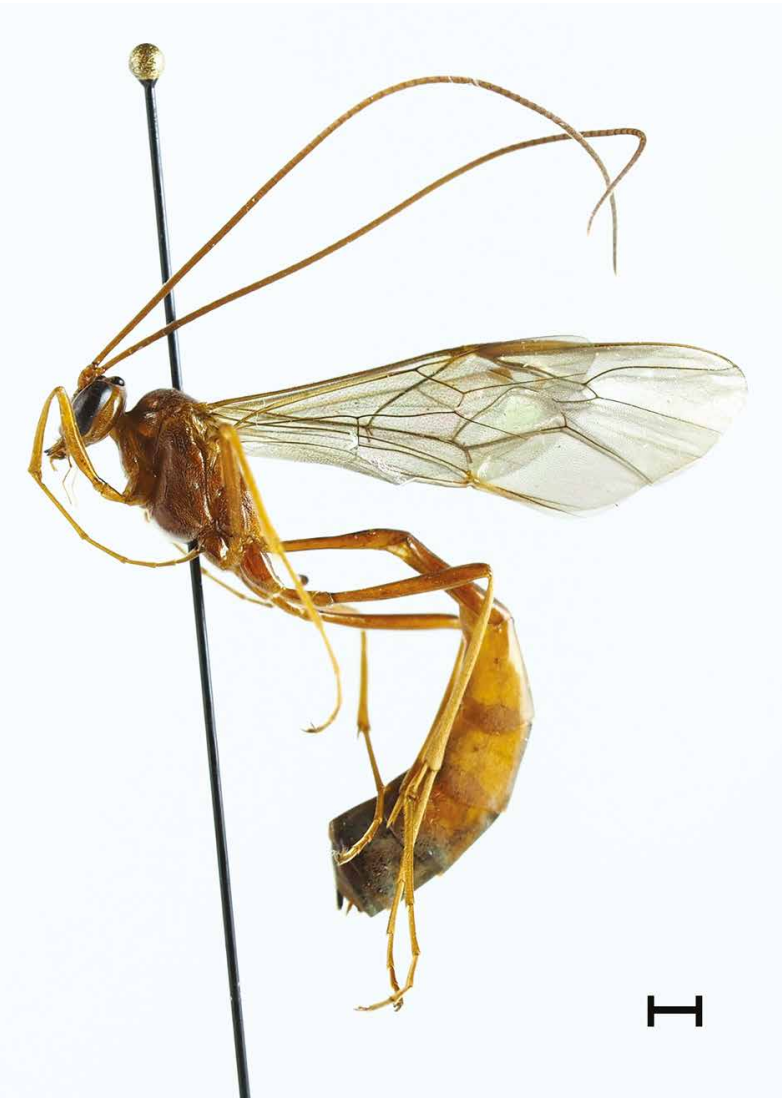

Fig. 8. Enicospilus intermedius sp. nov., holotype, + (NHRS-HEVA000008154), habitus, lateral view. Scale bar $=1 \mathrm{~mm}$. 


\section{Paratypes}

SWEDEN: 1 ㅇ, Uppland, Rådmansö, Bergholmen, $59.750^{\circ} \mathrm{N}, 18.953^{\circ} \mathrm{E}, \mathrm{MV}$-light trap, 29 Jul.18 Sep. 2017, N. Ryrholm and C. Källander leg. (NHRS-HEVA000008163); 1 + , Gästrikland, Gävle, Grinduga, $60.638^{\circ} \mathrm{N}, 17.294^{\circ} \mathrm{E}$, MV-light trap, 9-16 Jul. 2013, N. Ryrholm and C. Källander leg. (NHRS-HEVA000008164); 1 ○े, 2 우, Uppland, Rådmansö, Bergholmen, 59.750 $\mathrm{N}, 18.953^{\circ} \mathrm{E}, \mathrm{MV}-$ light trap, 18 Jun.-28 Jul. 2017, N. Ryrholm and C. Källander leg. (NHRS-HEVA000008165-NHRSHEVA000008167); 1 을 Gotland, Visby, Roleks, $57.572^{\circ} \mathrm{N}, 18.381^{\circ} \mathrm{E}$, Malaise trap in semi-open, grazed scots pine forest, 10 Apr.-06 Jun. 2005, SMTP leg. (NHRS-HEVA000008168); 1 \&, Sörmland, Huddinge, Sofielunds återvinningsstation, $59.187^{\circ} \mathrm{N}, 18.028^{\circ} \mathrm{E}$, Malaise trap in industrial area, 16 Jun.2 Jul. 2003, SMTP leg. (NHRS-HEVA000008169); 1 q, Gotland, Romakloster, Stenstugu Björke,
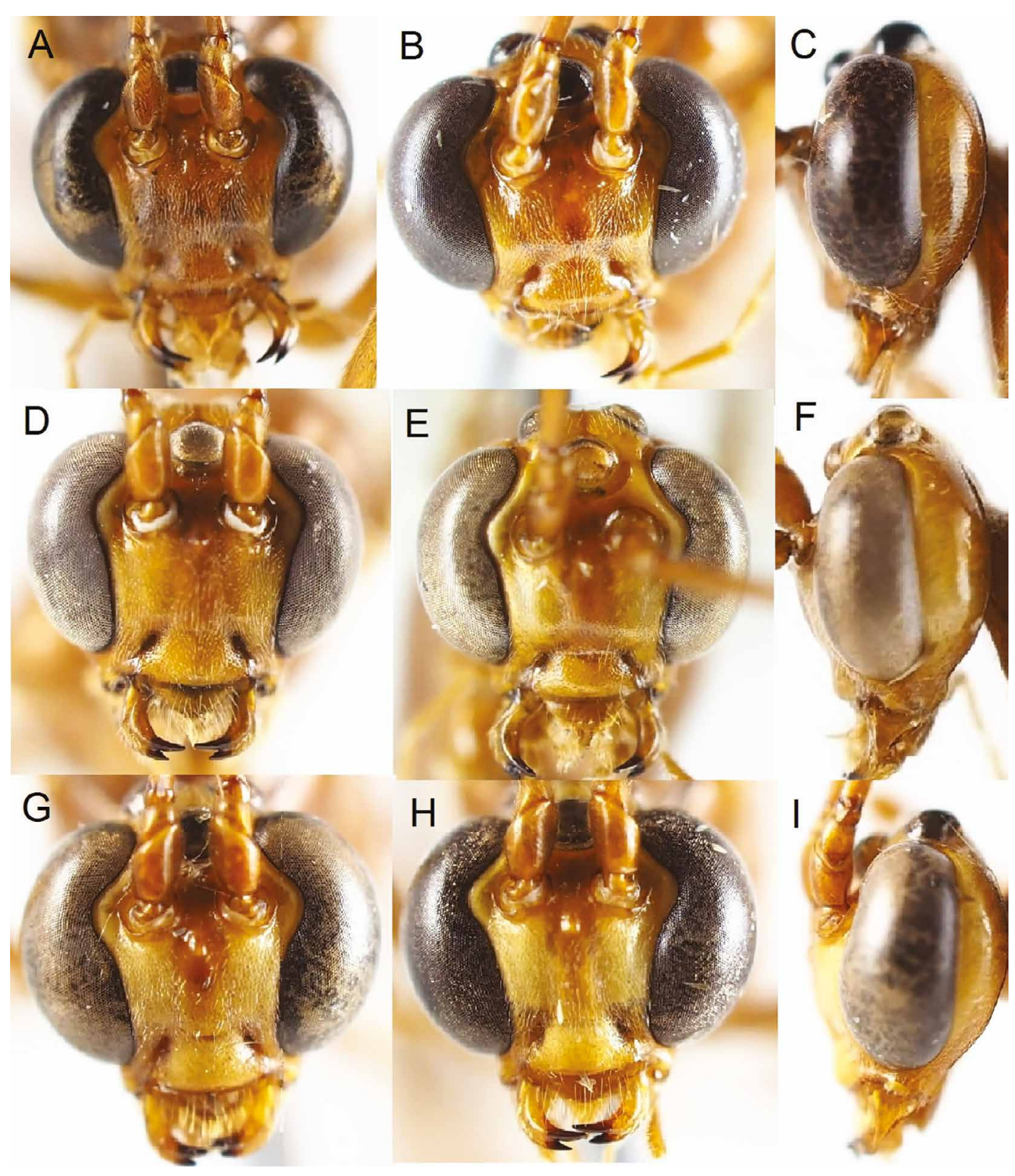

Fig. 9. Head, anterior and lateral view. A-C. Enicospilus intermedius sp. nov., paratypes, $q+$ (NHRS-HEVA000008171, NHRS-HEVA000008166). D-F. E. myricae Broad \& Shaw, 2016, 우․ G-I. E. adustus (Haller, 1885), 우으․ 
$57.514^{\circ} \mathrm{N}, 18.428^{\circ} \mathrm{E}, \mathrm{MV}-$ light, $17-24$ Jul. 2017, J. Törnvall leg. (NHRS-HEVA000008170); 1 , Gotland, Hamra, Suders, 56.940 ${ }^{\circ}$ N, $18.303^{\circ}$ E, MV-light trap, 21 Apr.-25 May 2007, N. Ryrholm and C. Källander leg. (NHRS-HEVA000008171).

\section{Description}

\section{Female}

Body length 19-21 mm. Fore wing length 15-16 mm. Number of flagellomeres 62-66 (mean 64). Mandible strongly twisted with upper tooth about two times as long as lower tooth. First flagellomere slender, about 4.5-5.0 times as long as apically wide. Mid- and preapical flagellomeres about 1.7 times as long as wide, shape of flagellomeres similar to E. adustus. Head in dorsal view usually with small gap of about 0.1 times ocellar diameter between inner orbit of compound eye and lateral ocellus, distinctly narrower than in E. myricae. Ocelli larger than in E. myricae. Temples buccate, in dorsal view curved, rounded immediately behind eye, distinctly wider than in E. adustus and in lateral view about 0.7 times width of compound eye (Fig. 9C). Occipital carina conspicuously curved before indicated junction with hypostomal carina. Indicated angle between occipital carina and hypostomal carina slightly acute or right angled (as in Fig. 6A). Clypeus apically truncate, moderately convex, in lateral view almost right angled, sparsely punctate, interstices shining. Mesopleuron closely punctate on a polished background, centrally becoming more rugose, intermixed with transverse striae. Epicnemial carina ventrally complete, sinuate, often indistinct or absent dorsally well before indicated joint with propleuron. Mesoscutum with notauli weakly indicated anteriorly, entirely closely punctate. Scutellum with lateral carinae, its surface with

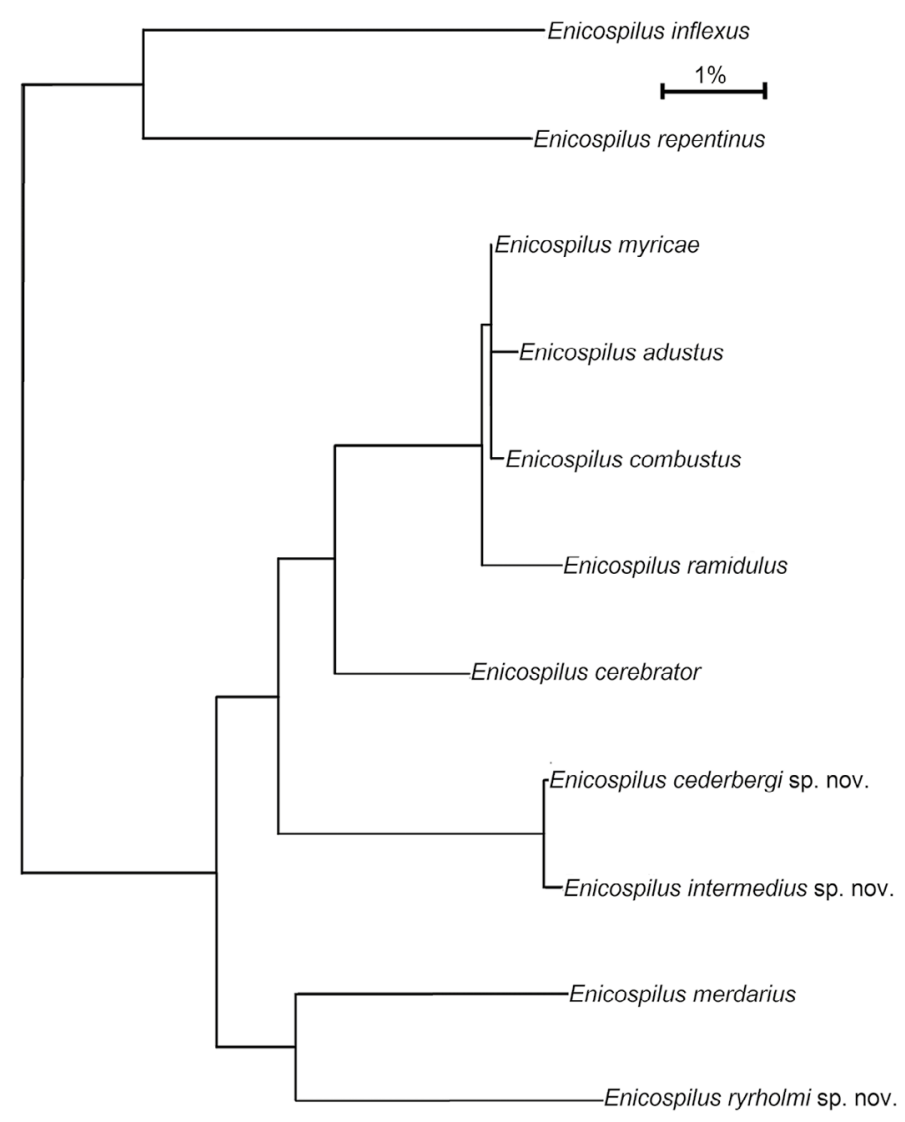

Fig. 10. Relationships among Swedish species of the genus Enicospilus according to their DNAbarcodes. The neighbour-joining phylogenetic tree was constructed on the basis of Kimura 2-parameter distances. All samples are from Sweden. The scale line indicates 1\% sequence divergence. 
dense punctures, punctures larger than on mesoscutum. Sclerites in fore wing identical to E. adustus (Fig. 4D) and E. myricae. Proximal sclerite entirely pigmented, approximately triangular with rounded anterior angle, central sclerite semi-circular, pigmented distally, fading to unpigmented proximally. Distal sclerite quite strong and elongate. Fore wing veins and pterostigma testaceous. Propodeum with anterior transverse carina strong, anterior of the carina rather densely punctate, posterior entirely reticulate-rugose often with faint longitudinal striae centrally. Legs of same proportions as in E. adustus.

\title{
Male
}

Size, structure and colour as in female. Antenna with slightly more numerous flagellomeres than in the female (65-67). Parameres long, in lateral view reminiscent of E. adustus (as in Fig. 7B). Based on the limited material of males and the fact that the parameres are often slightly deformed due to storage and chemical treatment, no detailed description can be made of the shape of the genitalia at this stage.

\section{Colour}

Uniformly testaceous. Inner and outer orbits usually only slightly paler than face (one male from Croatia with the undulation of the inner margin of compound eye and outer margin yellow); mandibular teeth black. Apical metasomal segments sometimes slightly infuscate. Ovipositor sheath usually darker than apical metasomal segments. Antennae slightly darker in apical half, but not as distinct as in typical specimens of E. myricae.

\section{DNA barcode}

The full DNA barcode sequence of one Swedish + of E. intermedius sp. nov. is available at the BOLD systems database (www.boldsystems.org, BIN; BOLD:AAI5191).

\section{Distribution}

Enicospilus intermedius sp. nov. is only known from the eastern parts of Central Sweden, including Gotland (Södermanland, Uppland, Gästrikland, Gotland), and Croatia (Sibensko Kninska).

\section{Phenology}

The dates on the labels of the type series range from late May to August. The main flight period is probably during June and July. In Southern Europe the species seems to be active during April and May.

\section{Ecology}

No detailed information on the biology of E. intermedius sp. nov. is known. The habitat in Sweden seems to mainly consist of semi-open xerothermic pine forests.

\author{
Enicospilus ryrholmi sp. nov. \\ urn:1sid:zoobank.org:act:75A2F3F0-0F8E-419A-A2D9-DD55298C7534 \\ Figs $3 \mathrm{G}-\mathrm{H}, 4 \mathrm{C}, 6 \mathrm{~B}, 10,11,12 \mathrm{~A}$
}

\section{Diagnosis}

Enicospilus ryrholmi sp. nov. can be distinguished from other members of the E. ramidulus species group by the position and shape of the central sclerite; the smaller size on average; the limited number of flagellomeres; the elongate central flagellomeres; the more or less straight mesopleural part of the epicnemial carina and the less curved lower part of the occipital carina. It is most likely to be confused with small specimens of E. adustus. 


\section{Etymology}

The name ryrholmi refers to the lepidopterologist Nils Ryrholm who, by sorting out and donating a large portion of Ophioninae from decades of sampling with MV-light traps, has contributed greatly to the taxonomy and knowledge of Scandinavian Enicospilus.

Material examined $(\mathrm{n}=15$ 우, 2 ふぇ)

\section{Holotype}

SWEDEN: 1 , Öland, Mörbylånga, Strandskogen, $56.698^{\circ} \mathrm{N}, 16.496^{\circ} \mathrm{E}, \mathrm{MV}$-light in garden close to an oak forest and sandy meadows, 23 Jul. 2016, M. Andersson leg. (NHRS-HEVA000008172 STI:NJBC159).

\section{Paratypes}

SWEDEN: 3 우, Skåne, Klippan, Bonnarpshed, $56.087^{\circ} \mathrm{N}, 13.180^{\circ} \mathrm{E}$, MV-light trap in open dry meadow, 9 Jul.-4 Aug. 2007, N. Ryrholm and C. Källander leg. (NHRS-HEVA000008173NHRS-HEVA000008175; 1 NHRS-HEVA000008175 STI:NJBC160); 2 + , , Skåne, Höganäs, Kullen, 56.293 ${ }^{\circ}$ N, $12.487^{\circ}$ E, 19 Jul. 1975, C.H. Lindroth leg. (MZLU Type no. 06123:2-3); 1 , Skåne, Höganäs, Kullen, 56.293 ${ }^{\circ}$ N, $12.487^{\circ}$ E, 2 Aug. 1975, C.H. Lindroth leg. (MZLU Type no. 06123:4); 1 , Öland, Mörbylånga, Räpplinge, $56.827^{\circ} \mathrm{N}, 16.660^{\circ} \mathrm{E}$, alvar/calcareous dry meadow, 26 Jul. 1980, L.-Å. Janzon leg. (MZLU Type no. 06123:5); 2 우, Småland, Sävsjö, Södra Hägnen, $57.379^{\circ} \mathrm{N}, 14.665^{\circ} \mathrm{E}, \mathrm{MV}$-light in open dry industrial area, 16 Aug. 2017, R. Isaksson leg. (NHRSHEVA000008176, NHRS-HEVA000008177); 1 ㅇ, Öland, Torslunda, Arontorp 56.637 $\mathrm{N}, 16.516^{\circ} \mathrm{E}$, MV-light, 9 Jul. 2017, T. Lindberg leg. (NHRS-HEVA000008178 STI:NJBC288); 1 , Gotland, Hamra, Tuvlandet, $56.966^{\circ} \mathrm{N}, 18.308^{\circ}$ E, MV-light trap, 15 Jul.-18 Aug. 2017, N. Ryrholm and C. Källander leg. (NHRS-HEVA000008179 STI:NJBC287); 1 q, Öland, Borgholm, 56.880 N, 16.656 ${ }^{\circ}$ E, 19 Jul.

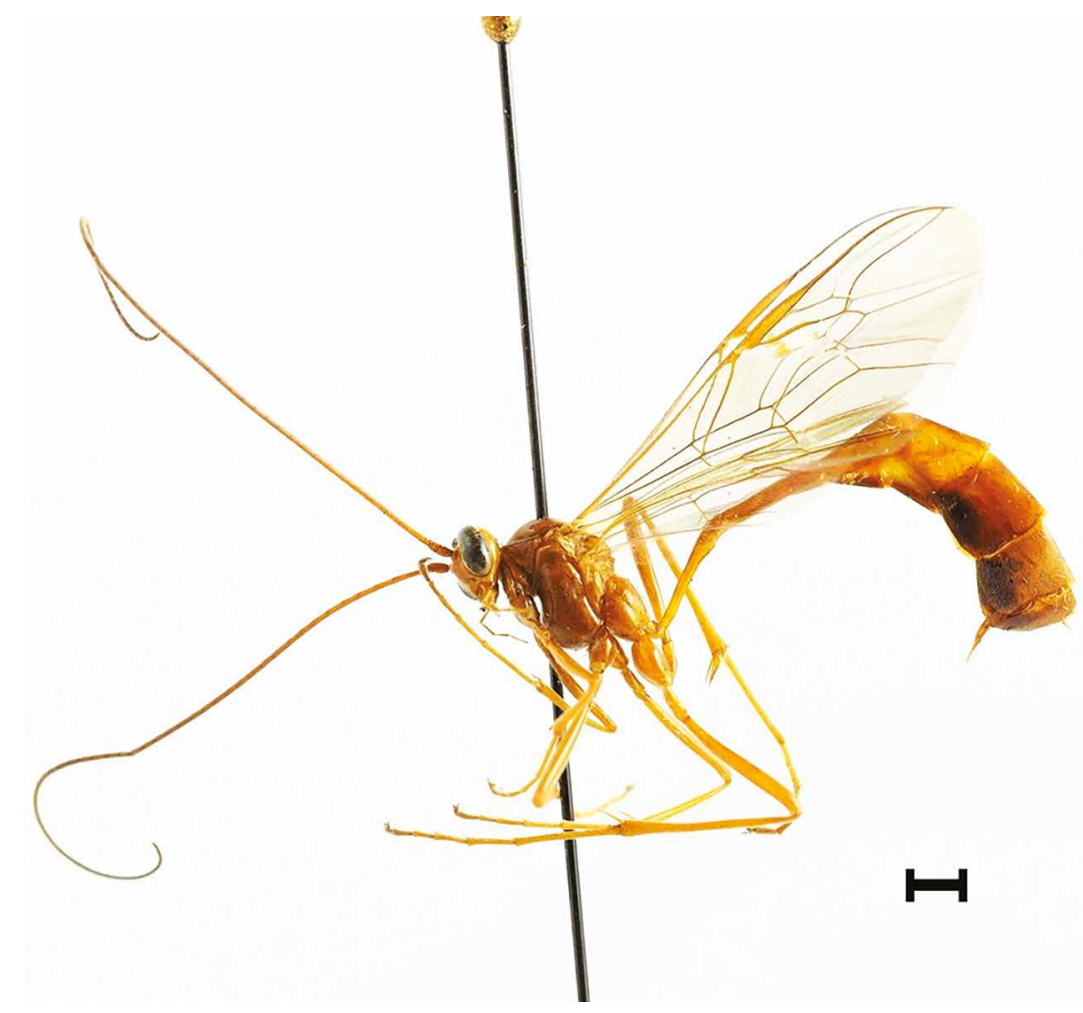

Fig. 11. Enicospilus ryrholmi sp. nov., holotype, $q$ (NHRS-HEVA000008172), habitus, lateral view. Scale bar $=1 \mathrm{~mm}$. 
1964, S. Johansson leg. (MZLU Type no. 06123:7); 1 ㅇ, Öland, Borgholm, 56.880 N, $16.656^{\circ} \mathrm{E}$,

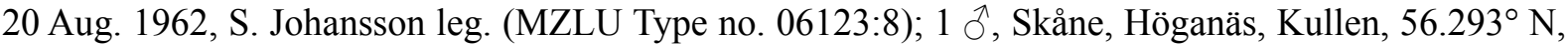
$12.487^{\circ}$ E, 28 Jun. 1975, C.H. Lindroth leg. (MZLU Type no. 06123:6); 1 ㅇ, Öland, Mörbylånga, Hagaberg Frö, 56.575 ${ }^{\circ}$ N, 16.448 E, 23 Jul. 1978, S. Johansson leg. (MZLU Type no. 06123:9); 1 ○, Öland, Mörbylånga, Karlsro, 56.579 ${ }^{\circ} \mathrm{N}, 16.421^{\circ} \mathrm{E}, 13 \mathrm{Jul}$. 1978, sweepnet in daylight, S. Johansson leg. (MZLU Type no. 06123:10).

\section{Description}

Female

Body length $16-17 \mathrm{~mm}$, fore wing length $12-13 \mathrm{~mm}$. Number of flagellomeres $51-56$ (mean 54). Mandible strongly twisted with upper tooth distinctly longer than lower tooth, usually slightly more than two times as long as lower tooth. First flagellomere very slender, about 5 times as long as apically wide. Central- and subapical flagellomeres slender, 2.0-2.1 times as long as wide (Fig. 3G-H). Head in dorsal view with small gap of about 0.1 times ocellar diameter between inner margin of compound eye and lateral ocellus. Temples in dorsal view narrowed behind eye as in typical specimens of $E$. adustus and in lateral view about 0.5 times the width of compound eye. Occipital carina only slightly curved before junction with hypostomal carina (Fig. 6B), joint sometimes indistinct or absent. Indicated angle between occipital carina and hypostomal carina acute, about 45 degrees. Clypeus apically truncate, convex in lateral view, very sparsely punctate. Mesopleuron punctate, weakly sculptured or polished, central punctures intermixed with vague transverse striae. Distance between punctures about two times diameter of punctures. Speculum without punctures, strongly polished. Epicnemial carina between pleurosternal angles and sternal part almost straight (Fig. 12A). Mesoscutum with notauli faintly indicated anteriorly, very sparsely and vaguely punctate. Sides of scutellum strongly converging posteriorly. Proximal sclerite entirely pigmented, approximately triangular with rounded anterior angle.

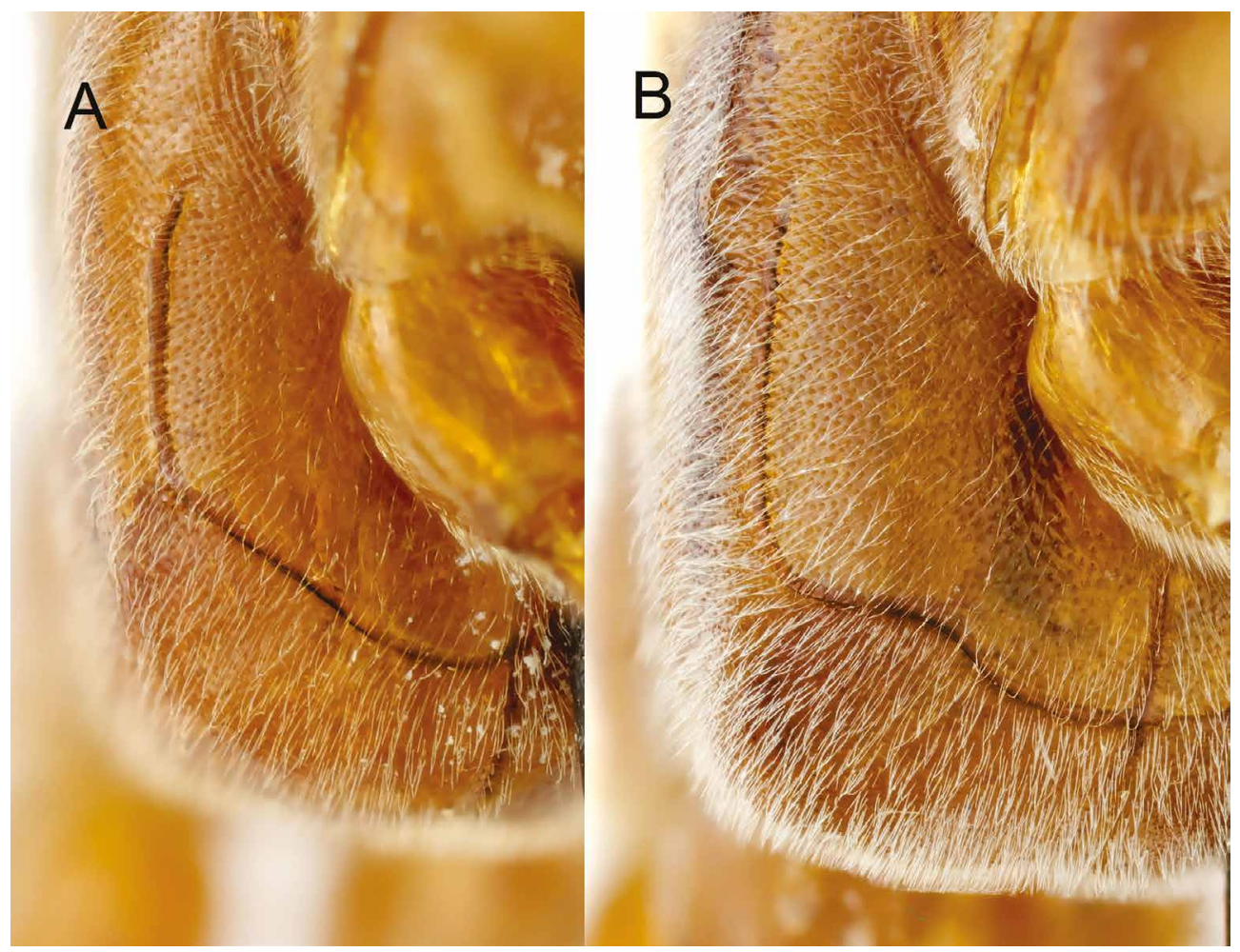

Fig. 12. Epicnemial carina, anterior view. A. Enicospilus ryrholmi sp. nov., paratype, $q$ (NHRSHEVA000008173). B. E. adustus (Haller, 1885), +. 
Central sclerite varying from almost unpigmented, reminiscent in shape of E. merdarius (Gravenhorst, $1829)$ but narrowly pigmented distally to more distinctly sclerotized and elongate. Distance between the proximal and central sclerites often smaller than in E. adustus and E. cerebrator (Fig. 4C). Fore wing veins thin, pale brownish. Pterostigma pale. Propodeum with anterior transverse carina strong, anterior of this rather densely punctate, posterior to this entirely reticulate-rugose often with faint longitudinal striae centrally. Proportion of legs as in E. adustus. Hind femur about 10 times as long as wide. Hind metatarsus about 12 times as long as wide.

\section{Male}

Size, structure and colour as in female. Parameres in lateral view short and obtuse as in E. ramidulus (Fig. 7A).

\section{Colour}

Uniformly testaceous. Metasoma sometimes slighty infuscate posteriorly. Mandibular teeth black.

\section{DNA barcode}

The full DNA barcode sequences of four of the Swedish E. ryrholmi sp. nov. specimens are available at the BOLD systems database (www.boldsystems.org, BIN;BOLD:ADF8803).

\section{Distribution}

Enicospilus ryrholmi sp. nov. is so far only known from Sweden where it seems to be rare but widespread at least in the southern part of the country, including the Baltic islands Öland and Gotland (Skåne, Blekinge, Småland, Öland, Gotland). It can, however, be expected to occur over a wider geographical range.

\section{Phenology}

The species occurs in late summer. The documented flight period is July to August.

\section{Ecology}

No detailed information on the biology of E. ryrholmi sp. nov. is known. The habitat consists mainly of semi-open areas ranging from alvar to rocky slopes, sandy heaths, industrial landscapes and gardens. The known localities might suggest a host connected to plants depending on open sandy or rocky grounds.

\section{Discussion}

This study recognizes 11 species of Enicospilus occurring in Sweden (Fig. 10). Nine of the species belong to the $E$. ramidulus species group. The barcoding in combination with the morphological analysis indicates that E. merdarius is to be regarded of a member of the E. ramidulus species group despite the unpigmented central sclerite. The barcoding results within the aggregates consisting of $E$. myricae, E. adustus, E. combustus and E. ramidulus on one hand and E. cederbergi sp. nov. and E. intermedius sp. nov. on the other, seem to display very small genetic differentiation despite the species being morphologically as well as ecologically distinct (Fig. 10) and several species seem to share the same BIN. These results could indicate that the chosen sequencing method might not be suitable for detecting and genetically defining closely related species in this genus, but might also be caused by distorting factors such as hybridization or low intraspecific genetic variation in the markers chosen. A more extended barcoding project including more specimens from a wider geographical range and a deeper analysis of the barcoding methods will probably shed more light on the detailed relation between the species involved. 


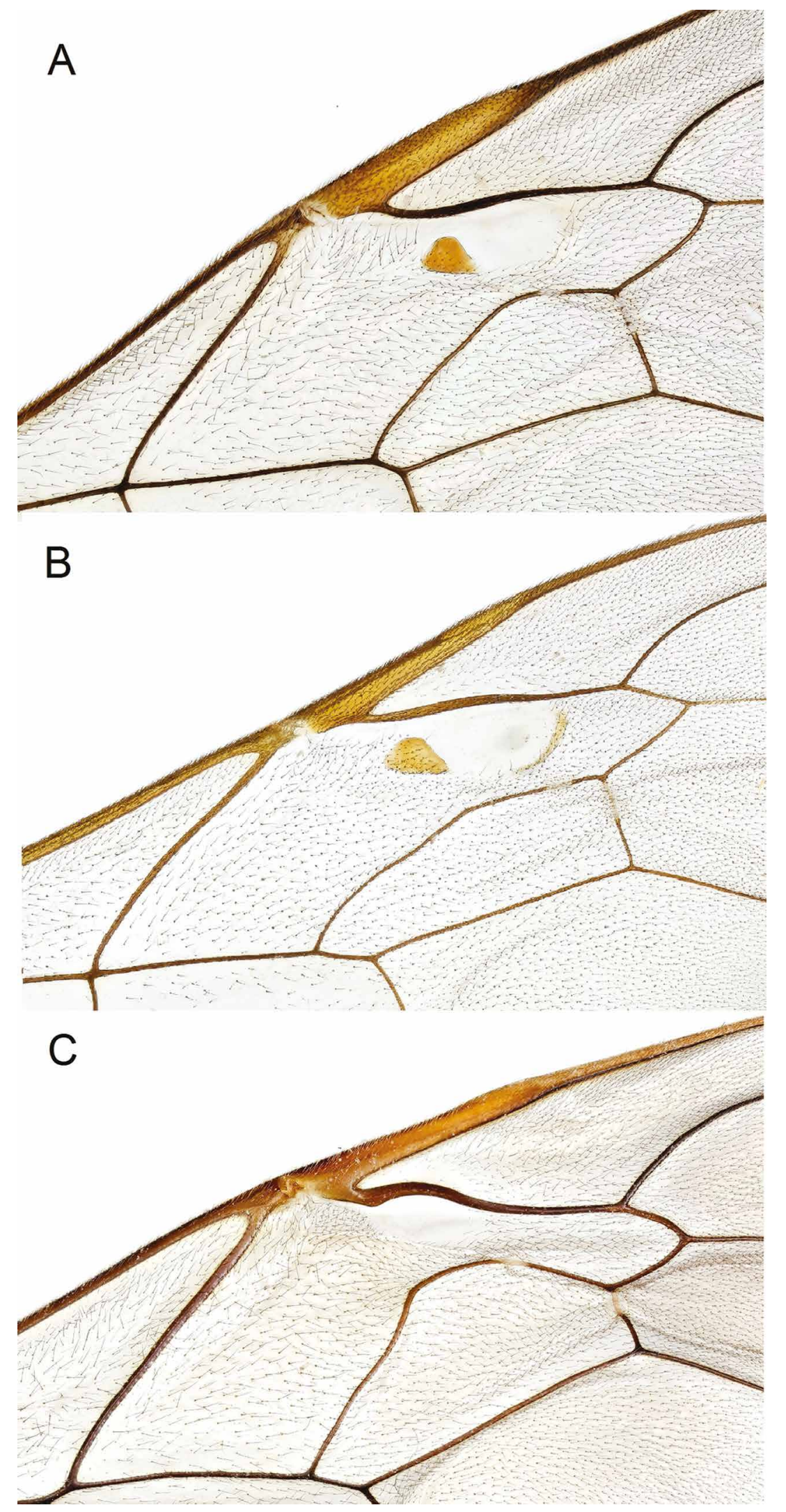

Fig. 13. Central part of fore wing. A. Enicospilus repentinus (Holmgren, 1860), ․ B. Enicospilus merdarius (Gravenhorst, 1829), ‥ C. Enicospilus inflexus (Ratzeburg, 1844), ‥ 
Apart from the three species described new to science, four species -Enicospilus myricae, E. combustus, E. merdarius and E. cerebrator - are reported as new to Sweden.

When it comes to the species and their abundance and distribution in Sweden, E. cerebrator seems to be a very rare species with predominately southern distribution and confined to open or semi-open, often calcareous grasslands. Enicospilus combustus prefers similar habitats as E. cerebrator, but is slightly more common, especially on the Baltic islands Öland and Gotland. Enicospilus myricae is also rather rare, but slightly more widespread in Southern and Central Sweden and seems to occur in several different habitats ranging from semi-open calcareous grasslands to semi-open pine dominated forests. This shows that the species seems to have a much wider habitat preference than referred to in the original description (Broad \& Shaw 2016) and probably can be expected to occur wherever the known host, the noctuid moth Orthosia gracilis, is present. Enicospilus merdarius is also a rather rare and local species known from a few coastal localities in Southern Sweden and on the Baltic island of Gotland.

Among the species previously recorded from Sweden, the distribution pattern for E. inflexus indicates that it is a rare but widespread species in Southern and Central Sweden. It shall hereby be noted that there are no Swedish records of the closely related E. undulatus (Gravenhorst, 1829). This rare parasitoid of Lasiocampa trifolii is known from Denmark and the Baltic countries and can be expected to occur in coastal heaths in Western Sweden where the host is quite common. Enicospilus repentinus is a widespread species in Southern and Central Sweden but rather rarely encountered. The remaining species, E. adustus and E. ramidulus, seem to be the most common, occurring all over Southern and Central Sweden in a wide variety of open and semi-open environments.

The dominance of the E. ramidulus species group in Northern Europe is interesting and might indicate that this is a predominately Palaearctic species complex. This is also indicated by the fact that the aggregate still holds several undescribed species in Central and Southern Europe. An ongoing wider revision of the Enicospilus of the Western Palaearctic will contribute to the knowledge of European Enicospilus and most likely reveal a significantly larger diversity than known today.

\section{Identification key to the Swedish species of Enicospilus}

1. Fore wing lacking sclerites in glabrous area of discosubmarginal cell (Fig. 13C); vein Rs+2r conspicuously curved before junction with pterostigma; large species, wing length about $20 \mathrm{~mm}$...................................................................................... inflexus (Ratzeburg, 1844) [For separation between E. inflexus (Ratzeburg, 1844) and E. undulatus (Gravenhorst, 1829), see Broad \& Shaw 2016.]

- Fore wing with at least one distinct sclerite in discosubmarginal cell (Figs 4A-D, 13A-B); vein Rs $+2 r$ slightly sinuate before junction with pterostigma; smaller species, wing length usually less than $16 \mathrm{~mm}$

2. Fore wing lacking any trace of central sclerite; distal sclerite very weak or absent (Fig. 13A); clypeus in lateral view flattened (Fig. 14B)

- Fore wing with central sclerite present, but sometimes completely translucent (Figs 4A-D, 13B); clypeus in lateral view distinctly convex (Fig. 14A) (E. ramidulus species group)

3. Fore wing with central sclerite completely translucent (Fig. 13B)

- Fore wing with central sclerite distinctly pigmented (Fig. 4A-D) 
4. Antenna with central and apical flagellomeres very slender with central and apical segments more than 2 times as long as wide (Fig. 3G-H); number of flagellomeres 53-56; occipital carina only slightly curved before indicated junction with hypostomal carina (Fig. 6B); epicnemial carina between mesopleural angles and sternal part almost straight (Fig. 12A); central sclerite in glabrous area in fore wing usually more circular in shape, largely unpigmented; central and proximal sclerite closer to each other (Fig. 4C). Small species, fore wing length 12-13 mm .......E. ryrholmi sp. nov.

- Antenna with central and apical flagellomeres at most 1.8 times as long as wide (Fig. 3A-F); occipital carina distinctly curved before indicated junction with hypostomal carina, (Fig. 6A); epicnemial carina between mesopleural angles and sternal part sinuous (Fig. 12B); central sclerite in glabrous area in fore wing more semi-ovoid in shape, often elongate; central and proximal sclerites further apart (Fig. 4A-B, D)

5. Mesosoma usually with extensive dark brown patches; central sclerite in fore wing mostly narrow, at most as long as wide (Fig. 4A); distance between central and proximal sclerites usually distinctly longer than basal side of proximal sclerite; central sclerite mostly entirely pigmented

E. combustus (Gravenhorst, 1829)

- Mesosoma lacking distinct dark patches, uniformly testaceous; central sclerite usually longer than wide (Fig. 4B-C); distance between central and proximal sclerites almost equal to basal side of proximal sclerite; central sclerite mostly largely unpigmented proximally

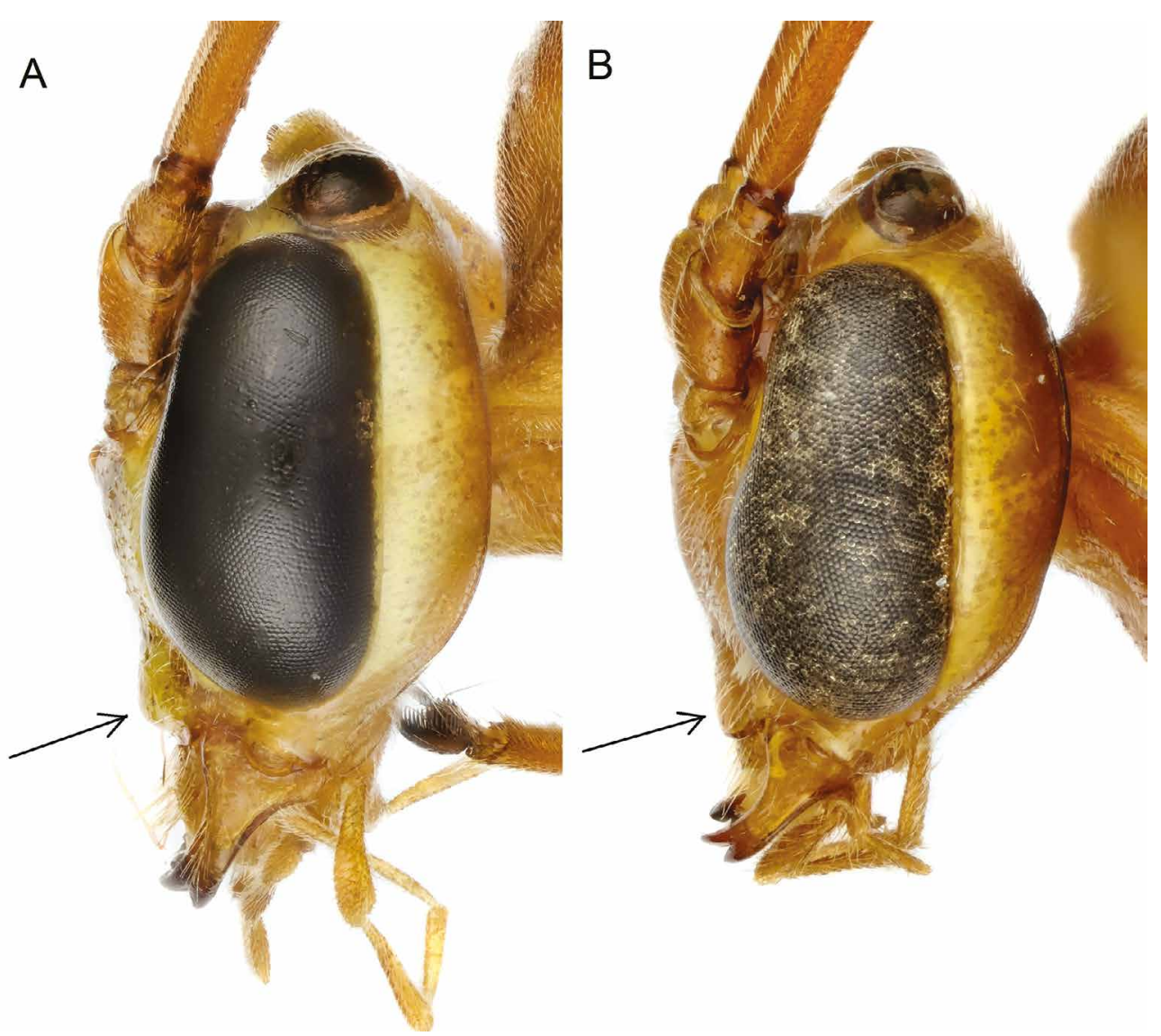

Fig. 14. Head in lateral view. A. Enicospilus merdarius (Gravenhorst, 1829), ๆ. B. Enicospilus repentinus (Holmgren, 1860), ㅇ․ 
6. Antenna with central and preapical flagellomeres shorter, at most 1.5 times as long as wide (Fig. 3A-D)

- Antenna with central and preapical flagellomeres longer, at least 1.7 times as long as wide (Fig. 3E-F)

7. Antenna with 51-56 flagellomeres; temples very strongly narrowed behind eyes, head with no gap between eye and lateral ocelli (Fig. 5A); central and apical flagellomeres about 1.3 times as long as wide (Fig. 3A-B)

E. cerebrator Aubert, 1966

- Antenna with 59-62 flagellomeres; temples strongly buccate, head with distinct gap between ocelli and eye (Fig. 5B); central and apical flagellomeres about 1.5 times as long as wide (Fig. 3C-D) E. cederbergi sp. nov.

8. Metasoma in female abruptly black-tipped from the 5th (in females) or 6th (in males) tergite; hind tarsal claws in female conspicuously curved (Fig. 15A). ..E. ramidulus (Linnaeus, 1758)

- Metasoma never abruptly black-tipped; hind tarsal claws in female not conspicuously curved (Fig. 15B)

9. Head in lateral view with temples narrow, at most about 0.4 times the width of compound eye (Fig. 9I); face generally with extensive yellow markings (Fig. 9G-H); face narrow in anterior view (Fig. 9G-H); lateral ocellus touching compound eye

E. adustus (Haller, 1885)

- Head in lateral view with temples wide, about 0.7 times the width of compound eye (Fig. 9C, F); face generally more testaceous; face wider in anterior view (Fig. 9A-B, D-E); lateral ocelli often with more or less distinct gap between lateral ocellus and compound eye 10
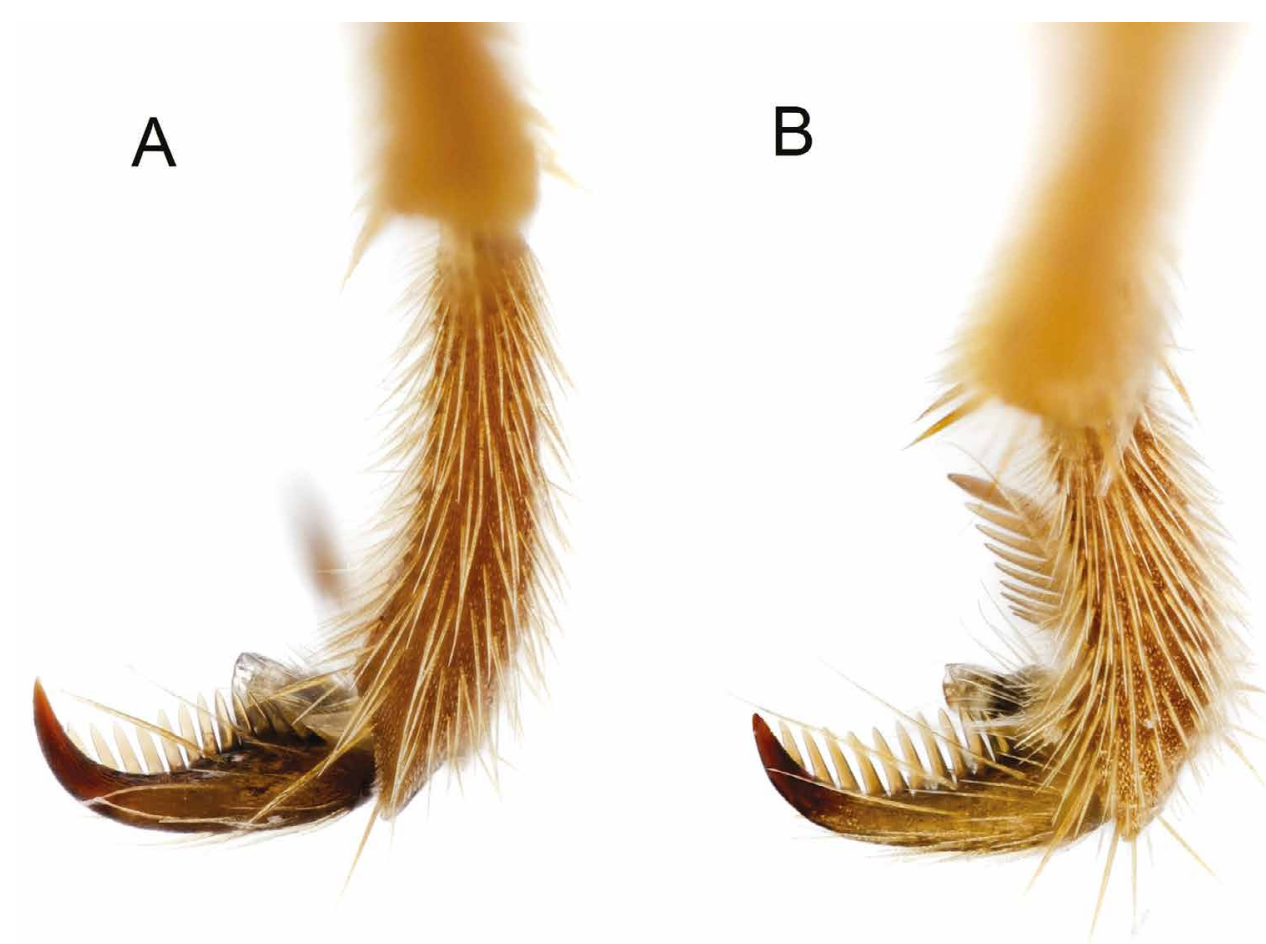

Fig. 15. Hind tarsal claws. A. Enicospilus ramidulus (Linnaeus, 1758), q. B. E. adustus (Haller, 1885), ㅇ․ 
10. Number of flagellomeres 56-59; head in anterior view more rounded (Fig. 9D-E); ocelli small, gap between lateral ocelli and inner margin of compound eye wide, about $0.2-0.3$ times the diameter of ocellus

E. myricae Broad \& Shaw, 2016

- Number of flagellomeres 62-67; head in anterior view distinctly transverse (Fig. 9A-B); ocelli large, gap between lateral ocelli and inner margin of compound eye narrow, about 0.1 times the diameter of ocellus

E. intermedius sp. nov

\section{Acknowledgements}

The author would like to thank Hege Vårdal (NHRS), Gavin Broad (BMNH), Mark Shaw (NMS), Michel Greeff and Andreas Müller (ETHZ) and Anne Freitag (MZLS) for administrating the loan and providing high-resolution pictures of relevant type material; Christoffer Fägerström, Christer Hansson \& Rune Bygebjerg (MZLU) for access to the collections; Björn Cederberg for sharing his accumulated knowledge on Swedish Enicospilus; Malin Strand at SweBOL, Gunnhild Marthinsen at NorBOL and The Swedish Taxonomy Initiative (STI) for assistance with the barcoding samples. DNA barcode data in this publication was in part generated in collaboration with the Norwegian Barcode of Life Network (NorBOL) funded by the Research Council of Norway and the Norwegian Biodiversity Information Centre. The author would also like to thank Robin Isaksson, Michael Andersson, Birgitta Andersson and Tommy Lindberg for donating series of specimens that helped sorting out the new species; Nils Ryrholm, Clas Källander and The Swedish Malaise Trap Project (SMTP) for sharing their samples and providing valuable information on the distribution of Swedish Enicospilus and Krister Hall for taking the close up photos presented in this paper.

\section{References}

Aubert J.F. 1966. Description de dix especes nouvelles s'ajoutant aux Ichneumonides de France et du Bassin mediterraneen. Bulletin de la Société entomologique de Mulhouse: 37-46.

Aubert J.F. 1979. Ichneumonides pétiolées inédites avec quatre genres nouveaux. Bulletin de la Société entomologique de Mulhouse: 1-8.

Bordera A.S., Selfa, J. \& Jiménez, R. 1987. Contribución al conocimiento del género Enicospilus Stephens, 1835 (Hym. Ichneumonidae) en España. Boletín de la Asociación Española de Entomología. Vol. 11: 221-233.

Broad G.R. \& Shaw M.R. 2016. The British species of Enicospilus (Hymenoptera: Ichneumonidae: Ophioninae). European Journal of Taxonomy 187: 1-31. https://doi.org/10.5852/ejt.2016.187

Funk D.J. \& Omland K.E. 2003. Species-level paraphyly and polyphyly: frequency, causes, and consequences, with insights from animal mitochondrial DNA. Annual Review of Ecology, Evolution and Systematics 34: 397-423. https://doi.org/10.1146/annurev.ecolsys.34.011802.132421

Gauld I.D. 1988. A survey of the Ophioninae (Hymenoptera: Ichneumonidae) of tropical Mesoamerica with special reference to the fauna of Costa Rica. Bulletin of the British Museum (Natural History), Entomology 57: 1-309.

Gauld I.D. 1991. The Ichneumonidae of Costa Rica 1. Memoirs of the American Entomological Institute 47. American Entomological Institute, Gainesville, FL.

Gauld I.D. \& Mitchell P.A. 1981. The taxonomy, distribution and host preferences of Indo-Papuan parasitic wasps of the subfamily Ophioninae. CAB, Slough, Commonwealth Institute of Entomology, London. 
Hebert P.D.N., Cywinska A., Ball S.L., deWaard, J.R. 2003. Biological identifications through DNA barcodes. Proceedings of the Royal Society London B: Biological Sciences 270: S96-S99.

https://doi.org/10.1098/rspb.2002.2218

Izquierdo I. 1983. Los Ophioninae españoles (Hym., Ichn.). Eos 59: 45-65.

Klopfstein S., Kropf C. \& Baur H. 2016. Wolbachia endosymbionts distort DNA barcoding in the parasitoid wasp genus Diplazon (Hymenoptera: Ichneumonidae). Zoological Journal of the Linnean Society 177: 541-557. https://doi.org/10.1111/zoj.12380

Kokujev N.R. 1907. Revue des especes Russes du genre Henicospilus. Trudy Russkago Entomologicheskago Obshchestva. [Horae Societatis Entomologicae Rossicae.] 38: 161-174.

Schwarzfeld M.D. \& Sperling F.A.H. 2014. Species delimitation using morphology, morphometrics, and molecules: definition of the Ophion scutellaris Thomson species group, with descriptions of six new species (Hymenoptera, Ichneumonidae). ZooKeys 462: 59-114.

https://doi.org/10.3897/zookeys.462.8229

Shestakov A. 1926. Tabula diagnostica et species novae palaearcticae generis Enicospilus Stephen. Konowia 5: 25-32.

Shimizu S. 2017. Description of a new species and revised key to species of the Enicospilus antefurcalis species-group from Japan (Hymenoptera: Ichneumonidae: Ophioninae). Acta Entomologica Musei Nationalis Pragae. Volume 57 (1): 183-194.

Viktorov G.A. 1957. Species of the genus Enicospilus (Hymenoptera, Ichneumonidae) Stephens in USSR. Entomologicheskoye Obozreniye 36: 179-210. [In Russian.]

Manuscript received: 22 June 2018

Manuscript accepted: 28 August 2018

Published on: 10 December 2018

Topic editor: Gavin Broad

Desk editor: Connie Baak

Printed versions of all papers are also deposited in the libraries of the institutes that are members of the EJT consortium: Muséum national d'Histoire naturelle, Paris, France; Meise Botanic Garden, Belgium; Royal Museum for Central Africa, Tervuren, Belgium; Natural History Museum, London, United Kingdom; Royal Belgian Institute of Natural Sciences, Brussels, Belgium; Natural History Museum of Denmark, Copenhagen, Denmark; Naturalis Biodiversity Center, Leiden, the Netherlands; Museo Nacional de Ciencias Naturales-CSIC, Madrid, Spain; Real Jardín Botánico de Madrid CSIC, Spain; Zoological Research Museum Alexander Koenig, Bonn, Germany. 